\title{
University Web Portals As Information Management Tool: Technology Acceptance Dimension
}

\author{
Marita N. Tolentino, University of the East, Philippines
}

\begin{abstract}
This study of the use of university web portal as information management tool identified the respondent's utilization and technology acceptance. The research aimed to: (1) to explore faculty members' acceptance of university web portal as an information management tool in teaching and (2) identify the key intention determinants of UE web portal use. With the forty (40) faculty respondents coming from the six (6) randomly selected colleges of the University of the East, the findings revealed that they have positive attitude towards the use of the portal as information management tool because of its usefulness and ease of use. The analysis depicts the respondents' full intention to continue using the university web portal. The result confirmed perceived usefulness (PU) as a determinant for behavioral intention to continue using the university web portal as information management tool.
\end{abstract}

Keywords: web portal; technology acceptance

\section{INTRODUCTION}

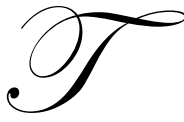

he advent of Internet technologies, specifically the World Wide Web (WWW), introduced a change in the teaching and learning mode from the traditional learning environment to online learning environment. The computer and Internet, combined, has become an important change agent, a significant educational and information management tool within the learning space.

Presently, more and more academics are using the web as information management tool to enrich teachinglearning beyond the traditional method. Information management (IM) refers to the use of technology in both the practice and study of acquiring, organizing, maintaining, retrieving and using information items, web pages and email messages to complete work-related tasks. Information flow between teachers and students, hence the need for efficient information management as part of pedagogy. Through the use of information management technology tool, teachers can have more time to make creative, intelligent use of the information at hand in order to effectively capture students' interest, meet their needs and optimize learning.

More universities have started initiatives on using information management tool to deliver education to students. The University of the East (UE) management has been very supportive in providing the needed technology for information management through the UE web Portal. The UE web Portal is a gateway for online information, lectures discussions, resources and other services exclusive to UE community. It offers various functions and services like viewing of grades, account balance, subject offerings, and other academic-related information. It also has the e-Learning and e-Forum as one of its major features.

\section{THEORETICAL BACKGROUND}

UE is proud of utilizing web portals available for use to faculty, students, alumni and other academic purposes. The UE web Portal facilitates communication between professors and students beyond class hours. It is available 24/7 (24 hours a day, 7 days a week) so the students can have unbounded access time to learning and they 
can do it anywhere, anytime, only limited by their own personal internet access capabilities. Students can download lecture materials posted by their teachers through this facility as well as perform view operations on various student records. It is protected by an access unique password, and no duplicate logins are permitted.

Through this facility, the UE faculty could gradually shift the learning environment from a purely classroom instruction-type to a more technology-integrated learning experience. The UE web Portal can be considered as an information management tool for acquiring, organizing, maintaining, retrieving and using information. However, most of the UE teachers are not using the Portal as information management technology in their instruction.

The success of the UE web Portal as information management tool depends on its acceptability to the teachers. Davis (1989) introduced and developed Technology Acceptance Model (TAM) that addresses the issue of how respondents move towards acceptance and use of technology and with the successful prediction about system use (Legris et al.2003). Figure 1 shows the TAM.

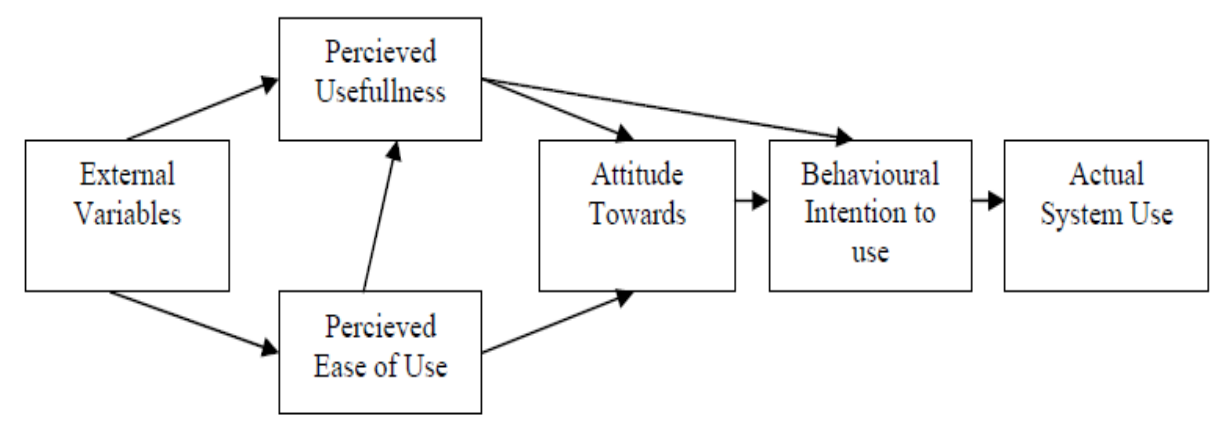

Figure 1. Original Technology Acceptance Model (Source: Legris et. al., 2003)

Davis (1989) defined perceived usefulness as the degree to which a person believes that using a particular system would enhance his or her job performance. On the other hand, Phillips et al. (1994) explained that Perceived Usefulness (PU) exemplify the users' subjective possibility that applying the new technology will be beneficial both for personal and organization's well-being.

Fred Davis (1989) defined this as the degree to which a person believes that using a particular system would be free from effort. This shows that, it is possible that educational technology with a high level of PU is more likely to induce positive attitudes. Furthermore, Moon \& Kim 2001), emphasize that Perceived Usefulness mediates the effect of Perceived Ease of Use on attitude. This gives an idea that PU has direct impacts on attitude, while PE influences attitude indirectly through PU.

Ma et al. (2005) opined that PU and PEU are two of the fundamental determinants in predicting an individual user's intention to use computer technology. A recent review found that these two variables received considerable attention in a great number of prior computer technology acceptance/adoption studies and were significant in both direct (PU) and indirect (PEU) effects on intention to computer technology use (e.g., Legris et al. 2003).

The technology acceptance model (Legris et. al. 2003) is related to four main factors: the perceived usefulness of technology; the perceived ease of use of technology; the attitudes toward the use of technology; and the behavioural intention to use the technology. As shown in Figure 1, perceived usefulness and perceived ease of use of technology builds positive attitudes toward the use of that technology. This positive attitude toward the use of technology will result to behavioral intention and to the actual use of technology. In this sense, four main factors of the TAM, shown in Figure 1, have been used as major determinants of technology acceptance in this study. 
Adapting the technology acceptance model, the researcher used the original paradigm of the TAM theory and aligned with it the different variables and terminologies used in this present study as presented in Figure 2.

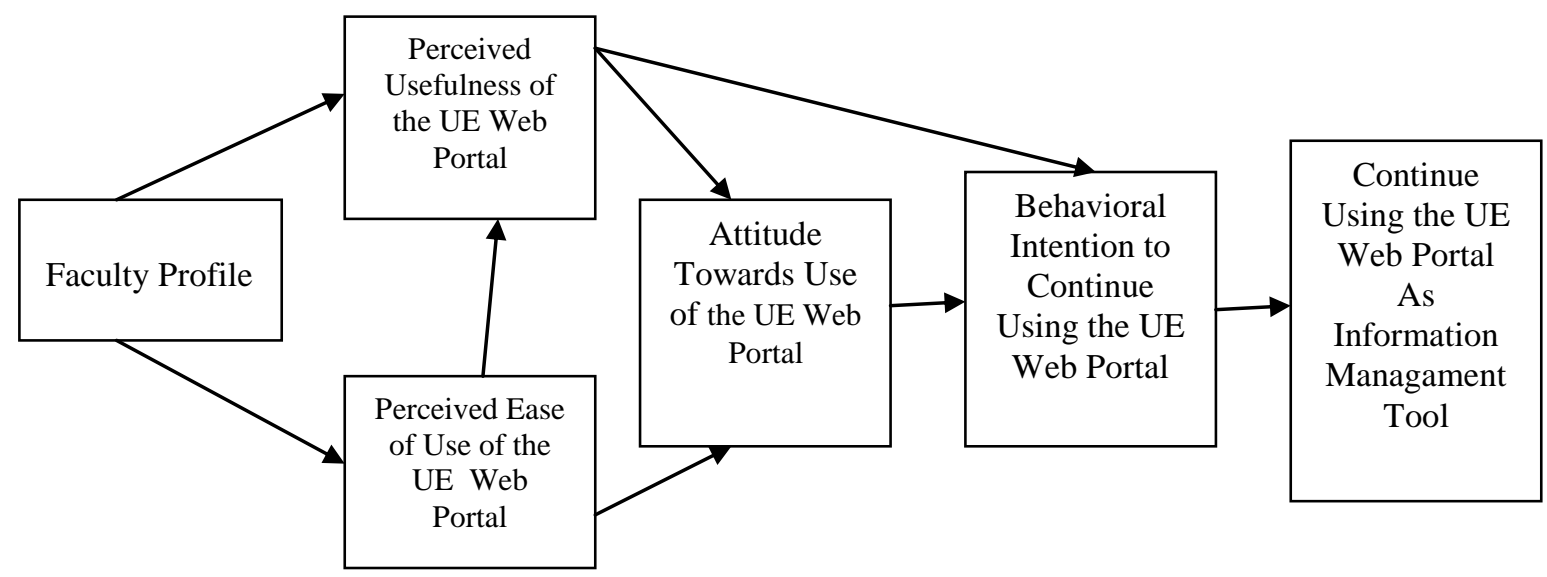

Figure 2. Modified Technology Acceptance Model (TAM) Patterned After Legris, 2003

\section{Profile As External Variable}

The significance of using the profile as external variable to increase the predictive power of technology acceptance was suggested by three known theorist: Davis (1993), Legris et al. (2003) and Zumd (1979). The present study included the external profile to determine the chain of influence from these variables to the dependent variable of interest.

\section{Perceived Usefulness of the University Web Portal}

Perceived usefulness, as the degree to which a person believes that using a particular technology will enhance his or her job performance, points that the teacher's use of the university web portal would help them increase their degree of effectiveness in the teaching-learning process.

\section{Perceived Ease-of-Use of the University Web Portal}

Perceived ease of use, as the degree to which a person believes that using a particular technology will be free of effort, emphasizes that the teacher's perception of the amount of effort required to utilize the university web portal will be effortless.

\section{Attitude Towards Use of the University Web Portal}

Social studies conducted show that attitude was a significant determinant of behavioral intention (e.g.,Fishbein \& Ajzen 1975; Ajzen 1988). Attitudes were also empirically tested as a strong intermediary for motivational variables to predict behavioral intention of technology use (e.g., Taylor \& Todd 1995). However, in a recent review by Will (2005), it was found that nearly half of the studies being reviewed found attitude nonsignificant and did not include attitude in their model framework (e.g., Legris et al. 2003). The researches somewhat reveal that attitude had been excluded from more recent use of technology acceptance studies.

\section{OBJECTIVE OF THE STUDY}

This study of the use of university web portal as information management tool identified the respondent's utilization and technology acceptance. The research aimed to: (1) to explore teachers' acceptance of university web portal as an information management tool in teaching and (2) identify the key intention determinants of UE web portal use. 
Teacher's acceptance of the use of the University web portal as an information management technology tool in teaching was determined in terms of the following variables: Perceived Usefulness, Perceived Ease of Use, and Attitude towards Use. Key intention determinants of portal use were identified from the same three variables.

The TAM served as a model to test the following hypothesis:

H1: A teacher's attitude towards use (AU) of University web portal is not significantly related to his or her perceived usefulness (PU) of the University web portal as information management tool.

H2: A teacher's attitude towards use (AU) of University web portal is not significantly related to his or her perceived ease of use (PE) of the University web portal as information management tool.

H3: A teacher's perceived usefulness (PU) of the University web portal is not significantly related to his or her perceived ease of use (PE) of the University web portal as information management tool.

H4: A teacher's behavioural intention to continue using (BIU) the University web portal is not significantly related to his perceived usefulness (PU) of the University web portal as information management tool.

H5: A teacher's behavioural intention to continue using (BIU) the University web portal is not significantly related to his perceived ease of use (PE) of the University web portal as information management tool.

H6: A teacher's behavioural intention to continue using (BIU) the University web portal is not significantly related to his or her attitude towards use (AU) of the University web portal as information management tool.

H7. A teacher's technology acceptance factors, namely, perceived usefulness (PU) and perceived ease of use (PE) are not determinants of their behavioral intention to continue using (BIU) the University web portal.

\section{RESEARCH DESIGN AND PROCEDURE}

The respondents of the study are the forty (40) faculty members from all the colleges of the University of the East - Manila. The Manila campus caters to several colleges namely, College of Business Administration (CBA), College of Arts and Sciences (CAS), College of Education (CoEd), College of Engineering (CoE), College of Computers Studies and Systems (CCSS), and College of Dentistry (CoD).

There were only a few number of faculty members utilizing the UE web Portal as Information Management tool in teaching. This study utilized purposive technique in choosing the respondents - only those faculty members who specifically fit in the set requirement were chosen as respondents. This process initially involved interview method to determine who UE web Portal users are. The researcher also used snow-ball effect in locating possible qualified respondents. Snowball effect is a figurative term for a process that starts from an initial state of where something once small builds upon itself, grows exponentially at a swift pace becoming larger, engulfing everything in its path. Thus, when all means were tried and exhausted, the chosen respondents whether small in number were considered population of the study.

The said study was conducted during the second semester of school year 2009 - 2010. The findings, therefore, are true only for this time covered and for the chosen respondents.

The data gathered through survey questionnaire is considered as primary data directly taken from the respondents - their profile, perceived usefulness and ease of use of the University web portal as information management tool, as well as, their attitude towards use of the University web portal. These variables, singly or in combination, were tested if they are intention determinants (predictors) of the respondents behavioral intention to continue using the University web portal as information management tool.

\section{INSTRUMENTS FOR GATHERING DATA AND VALIDATION}

The survey questionnaire was adapted from the study of Siong and Woods (2007). The validated questionnaire items used to operationalize the theoretical constructs were in principal adopted from prior research and revised for use in the University web portal as information management tool context. 
The questionnaire is consisted of four (4) sections - Part I - is the demographics. Part II - determined the technology acceptance of the respondents in terms of the two (2) indicators perceived usefulness and perceived ease of use. Part III and Part IV sections - determines the respondent's attitude towards use of the University web portal and their behavioral intention to continue to use it as an information management technology tool in teaching.

As mentioned in the study by Siong and Woods (2007), Part II section is adapted from Legris et al (2003). Part III the Attitudes toward computer use section is adapted from a questionnaire developed adapted from Thompson et al. (1991).

The instrument is composed of 18 statements on PU (six items), PE (five items), Attitude (five items) and Behavioral Intention (two items). Participants gave their opinions to each statement on a 5-point Likert scale, ranging from 1 (strongly disagree) to 5 (strongly agree).

To establish the questionnaire's validity, the researcher performed two (2) validation procedures: 1) face validity, and 2) validation by computing using spearman's rho coefficient. The coefficient of correlation was computed to test for consistency in responses of ten (10) faculty members who were asked to answer the questionnaire twice at two different times. The formula used was Spearman's rho with a computed coefficient of 0.76 or 0.80 .

\section{DATA ANALYSIS AND RESULTS}

\section{Profile of the Respondents}

Findings revealed that of the forty (40) faculty respondents of the study, seventeen (17) or 42 percent are aged 36 years and above. Twelve (12) or 30 percent belongs to $31-35$ age brackets, seven (7) or $18 \%$ are $19-24$ years old and four (4) or $10 \%$ are $25-30$ years old.

Result shows that majority ( 24 or $60 \%$ ) of the faculty respondents are female while sixteen (16) or 40 percent are males.

Majority of the faculty respondents, nineteen (19) or 48 percent belongs to the College of Computer Studies and Systems, followed by seven (7) or 17\% from the College of Dentistry. The rest are from College of Arts and Sciences (3 or 7\%), College of Business Administration (5 or 13\%), College of Education (2 or 5\%), and College of Engineering (4 or 10\%). They are the faculty who are using the University web portal as an information management.

Most of the faculty respondents of this study are masters degree holders (11 or 28\%), and some are with Doctorate units (15 or $38 \%$ ). This is in line with University of the East requirement that faculty members should be, at least, masters degree holder.

Thirty-five percent $(35 \%)$ of the faculty respondents have been serving the University for $6-10$ years. Eleven percent (11\%) belongs to the less than 5 years bracket; ten (10) or 25 percent have been in service for 11 15 years, and five (5) or 12 percent for more than sixteen (16) years.

\section{Description of the Respondents on the UE web Portal}

\section{Perceived Usefulness}

A mean perception of 4.03 revealed that, overall, the faculty respondents agreed that they found the University web portal useful in education. Moreover, they agreed $(\mathrm{WM}=4.08)$ that the use of University web portal enables them to accomplish tasks more quickly and enhances their educational effectiveness. They also strongly agreed (WM = 3.83) that the University web portal increases their performance in education. However, it may be noted that with the lowest mean of 3.63, the respondents agreed that the use of University web portal enhances their educational effectiveness. The overall weighted mean of 3.93 indicated that the faculty respondents perceived that computer technology is useful. 


\section{Perceived Ease Of Use}

As to the ease of use of the University web portal, the weighted mean of 3.98 shows that the respondents agreed they seldom become confused while working with the University web portal because their interaction with the University web portal is clear and understandable. The faculty respondents agreed that learning to operate (WM $=4.20)$ and use (WM $=4.30)$ the University web portal is easy. Overall, they find the University web portal easy to use (4.08). Averaging the responses, the overall weighted mean of 4.11 showed that the faculty respondents find the University web portal easy to use.

\section{Extent of Respondents' Attitude Towards Use Of The UE Portal}

As regards the faculty respondent's attitude towards the use of the University web portal, they agreed that they look forward to those aspects of their job that require them to use University web portals ( $\mathrm{WM}=3.90)$, the use of University web Portal makes teaching more interesting $(\mathrm{WM}=3.75)$, teaching with the use of with the University web portal is fun (WM =3.63). However, the faculty respondents are undecided ( $\mathrm{WM}=2.80)$ whether they want to use other method of teaching once they started to use the University web portal. The overall weighted mean of 3.58 proved that the faculty respondents have positive attitude towards the use of the University web portal.

\section{Extent Of Respondents' Behavioral Intention To Continue Using The UE Web Portal}

When it comes to the faculty respondents' behavioral intention to continue using the University web portal, the weighted mean of 3.85 displays agreement that whenever possible, they intend to continuously use the University web portal in my future teaching ( $\mathrm{WM}=3.85)$. The lowest overall weighted mean of 3.80 evidence that to the extent possible, they intend to continuously use the University web portal in doing different teaching tasks. The overall weighted mean of 3.83 depicted they have full intention to continue using the University web portal.

\section{Relationships Between Or Among The Technology Acceptance Factors And The Behavioral Intention To Continue Using The Ue Web Portal}

Table 1 depicts substantial correlation $(\mathrm{r}=0.674$ between perceived usefulness (PU) and the faculty respondents' behavioral intention to continue using (BIU) the University web portal. Perceived usefulness (PU) is also seen to be highly correlated with attitude towards use (AU) of University web portal $(r=0.864)$. Both cited relationships with perceived usefulness are significant at 0.01 level of significance, thus, Hypothes1s 1 and Hypothesis 4 is rejected.

In terms of perceived ease of use (PEU), the result revealed that it has substantial correlation with attitude towards use $(\mathrm{AU})$ of University web portal $(\mathrm{r}=0.409)$. Further test revealed the $\mathrm{p}$-value of 0.009 is significant at 0.01 level of significance, thus, Hypothesis 2 is rejected.

It is worthy to note that high correlation $(\mathrm{r}=0.795)$ is observed between attitude towards use (AU) of University web portal and the faculty respondents' behavioral intention to continue using (BIU) the University web portal. The relationship is significant at 0.01 level of significance, thus, Hypothesis 6 is rejected.

The foregoing findings lead the researcher to accept the null hypotheses 3 and 5 that there are no significant relationship between perceived usefulness (PU) and perceived ease of use (PE); perceived ease of use (PE) and behavioral intention to continue using (BIU) the University web portal. 
Table 1. Correlation Matrix Showing The Relationships Between Or Among The Technology Acceptance Factors And The Behavioral Intention To Continue Using The UE Portal

\begin{tabular}{|l|l|c|c|c|}
\hline \multicolumn{5}{|c|}{ Acceptance Factors And The Behavioral Intention To Continue Using The UE Portal } \\
\hline PU & Pearson Correlation & PU & PEU & AU \\
\hline & Sig. (2-tailed) & & 0.290 & $0.864(* *)$ \\
\hline PEU & Pearson Correlation & 0.290 & 0.070 & 0.000 \\
\hline & Sig. (2-tailed) & 0.070 & 1 & $0.409(* *)$ \\
\hline AU & Pearson Correlation & $0.864(* *)$ & $0.409(* *)$ & 0.009 \\
\hline & Sig. (2-tailed) & 0.000 & 0.009 & 1 \\
\hline BIU & Pearson Correlation & $0.674(* *)$ & 0.247 & $0.795(* *)$ \\
\hline & Sig. (2-tailed) & 0.000 & 0.124 & 0.000 \\
\hline
\end{tabular}

* Correlation is significant at the 0.01 level (2-tailed).

\section{Intention Determinants To Continue Using The UE Web Portal}

Taken singly, the perceived usefulness (PU) is found to be a determinant for the respondents' behavioral intention to continue using the University web portal. The coefficient of determination $\mathrm{R}^{2}=0.445$ revealed that $45.5 \%$ of the variability in the behavioral intention to continue using the University web portal can be explained by the variability of the perceived usefulness (PU). However, the coefficient of determination $\mathrm{R}^{2}=0.061$ revealed that only $6.1 \%$ of the variability in the behavioral intention to continue using the University web portal can be explained by the variability of the perceived ease of use (PE), as shown in Table 2.

The computed p-value $=0.000$ of PU is less than the 0.05 level of significance, thus, the null hypothesis stated in Chapter 2 is rejected. While the computed p-value $=0.124$ is greater than the 0.05 level of significance, thus, the null hypothesis that PE is not a determinant of BIU is accepted. This only shows that among the two (2) factors, PU is a determinant of the respondents' behavioral intention to continue using the University web portal.

Table 2. ANOVA Table of Regression Analysis

\begin{tabular}{|l|l|c|c|}
\hline \multicolumn{1}{|c|}{ Dependent Variable } & \multicolumn{1}{|c|}{ Independent Variables } & $\mathbf{R}^{2}$ & F-value (p-value) \\
\hline \multirow{2}{*}{$\begin{array}{l}\text { Behavioral Intention to Continue } \\
\text { Using the UE Web Portal (BIU) }\end{array}$} & Perceived Usefulness (PU) & 0.455 & $31.702(0.000)^{*}$ \\
\cline { 2 - 4 } & Perceived Ease of Use (PE) & 0.061 & $2.478(0.124)^{*}$ \\
\hline
\end{tabular}

* $\mathbf{r}$ is significant if $\mathrm{p}$-value $<0.05$

Predictors: (Constant), PU and PE

Dependent: Behavioral Intention to Use (BIU)

Taken collectively, the coefficient of determination $\mathrm{R}^{2}=0.458$ revealed that $45.8 \%$ of the variability in the respondents' behavioral intention to continue using the University web portal can be explained by the variability of their perception in the PU and PE, as shown in Table 3.

Table 3. ANOVA Table Of Regression Analysis

\begin{tabular}{|l|l|c|c|}
\hline \multicolumn{1}{|c|}{ Dependent Variable } & Independent Variables & $\mathbf{R}^{\mathbf{2}} \mathbf{( 1 0 0 \% )}$ & F-value (p-value) \\
\hline \multirow{2}{*}{$\begin{array}{l}\text { Behavioral Intention to Continue } \\
\text { Using the UE Web Portal (BIU) }\end{array}$} & Perceived Usefulness (PU) & \multirow{2}{*}{0.458} & $15.620(0.000)^{*}$ \\
\cline { 2 - 4 } & Perceived Ease of Use (PE) & & \\
\hline
\end{tabular}

* $\mathbf{r}$ is significant if $\mathrm{p}$-value $<0.05$

Predictors: (Constant), PU and PE 
Dependent: Behavioral Intention to Use (BIU)

The regression equation for the behavioral intention to continue using the University web portal is:

$$
B I U=1.269-0.582 P U-0.068 P E
$$
rejected.

The computed $\mathrm{p}$-value $=0.000$ is less than the 0.05 level of significance, thus, the null hypothesis is

\section{CONCLUSION}

The findings of the study provided the basis in the formulation of the conclusions that follow:

1. Most of the respondents are aged 31 and above, females, belonging to CCSS, masters degree holder with doctorate units, and have been serving the university for $6-10$ years.

2. In terms of the technology acceptance factors, the UE Portal is perceived by the faculty respondents as useful and easy to use.

3. The faculty respondents have positive attitude towards the use of the UE portal and that they have full intention to continue using the UE portal.

4. Substantial relationship exists between the faculty respondents' perceived usefulness and behavioral intention to use the UE portal, while high relationship with their attitude towards use of the UE portal. Also, Substantial relationship exists between the faculty respondents' perceived ease of use and attitude towards use of UE portal. Lastly, high relationship exists between attitude towards use of UE portal and the faculty respondents' behavioral intention to continue using the UE portal. The research rejected the null hypothesis stated in reference to this relationships tested.

5. Taken singly, the perceived usefulness (PU) is found to be a determinant for the respondents' behavioral intention to continue using the UE portal. Taken collectively, $45.8 \%$ of the variability in the respondents' behavioral intention to continue using the UE portal can be explained by the variability of their perception in the PU and PE. The regression equation for the behavioral intention to continue using the UE portal is: $\mathrm{BIU}=1.269-0.582 \mathrm{PU}-0.068 \mathrm{PE}$.

6. Several problems were cited by the faculty respondents as regards their use of the UE portal.

\section{AUTHOR INFORMATION}

Marita Nato Tolentino is married with one (1) child. She is presently a regular faculty member for 4 years at the College of Computer Studies and Systems (CCSS), University of the East (UE), Manila, Philippines. She finished Master in Information Management (MIM) and teaches computers courses for Computer Science and Information Technology students.

\section{REFERENCES}

1. Ahuja, M. K., \& Thatcher, J. B. (2005). Moving beyond intentions and toward the theory of trying: Effects of work environment and gender on post-adoption information technology use. MIS Quarterly, 29, 427-459.

2. Acceptance model to assess outcomes in a globally linked strategic communication project. (2006, January 1). Journalism \& Mass Communication Educator.

3. Applying the technology acceptance model to assess outcomes in a globally linked strategic communication project. (2006, January 1). Journalism \& Mass Communication Educator.

4. Bagozzi, (1992). Technology acceptance model history. Retrieved March 2, 2010, from http://en.wikipedia.org/wiki/Technology acceptance model

5. Bannan, B., \& Milheim, W. D. (1997). Existing Web-Based instruction courses and their design. In Khan, B. H. (Ed.). Web-based instruction (pp. 381-387). Englewood Cliffs, New Jersey: Educational Technology Pub. Inc.

6. Batagan, L., Pocovnicu, A. \& Capisizu, S., E. service-quality management (2009, September 30). Journal 
Home, 4.

7. Bolton, (2008, April). The University of York: Web redevelopment project. Higher Education Sector Research Report on Institutional Portals. Retrieved February 9, 2010, from www.york.ac.uk/weboffice/projects/redevelopment/portal_report_comparators.pdf

8. Bringula, R. \& Basa, R. (2008). Factors affecting web portal usability inputs for faculty web portal development of the University of the East. School Year 2007-2008. University of the East funded reasearch, Manila, Philippines.

9. Chang, V., \& Fisher, D. The Validation and Application of a New Learning Environment Instrument to Evaluate Online Learning in Higher Education. Retrieved October 9, 2010, from http://www.aare.edu.au/01pap/cha01098.htm

10. Chu, F. L. Extending the technology acceptance model to investigate the factors affecting the user satisfaction in internet banking. Business and information (2009). Malaysia (July 06-08). Retrieved January 6, 2010, from bai2009.org/file/Papers/1411.doc

11. Davis, F. D., Bagozzi, R., \& Warshaw, P. R. (1989). User acceptance of computer technology: A comparison of two theoretical models. Management Science, 35, 982-1003.

12. Davies, F. D. (1989). Perceived usefulness, perceived ease of use and user acceptance. MIS Quarterly, 13, 319-341.

13. Dusick, D., \& Yildrim, S. (2000). Faculty computer use and training: Identifying distinct needs for different populations. Community College Review, 27, 33-47.

14. Fishbein, M., \& Ajzen, I. (1975). Belief, attitude, intention, and behavior; An introduction to theory and research, reading, MA: Addison-Wesley. Retrived January 15, 2010, from http://www.amazon.com/Belief-Attitude-Intention-Behavior-Addison-Wesley/

15. Gao, Yuan. Applying the technology acceptance model (Tam) to educational hypermedia. Retrieved October 9, 2009, from

http://www.thefreelibrary.com/Applying+the+Technology+Acceptance+Model+(TAM)+to+educational$\underline{\mathrm{a} 0139920600}$

16. Gong, M., Xu, Y., \& Yu, Y. An enhanced technology acceptance model for web-based learning. Retrieved December 9, 2009, from http:// www.allbusiness.com/technology/947120-1.html

17. Information management and processing. Retrieved December 10, 2009, from http://www.referenceforbusiness.com/encyclopedia/Inc-Int/Information Management-and-Processing.html

18. Institutional Portals-formative evaluation of educational benefits, A Non-Profit corporation. Retrieved March 30, 2010, from www.tltgroup.org/flashlight/handbook

19. Jenkins, J. (1999). Teaching for tomorrow the changing role of teachers in the connected classroom. EDEN Open Class Room Conference Balatonfured. Consultancy in distance education. Retrieved January 6, 2010, from http://www.eden-online.org/papers/jenkins.pdf

20. Jones, D. (2005). Virtual learning environments: three implementation perpective. Retrieved October 11, 2009, from http://davidtjones.wordpress.com/2009/03/13/virtual-learning-environments-threeimplementation-perspectives/

21. Johnson, M., Foa, L., \& Schwab (1999). Technology as a agent for the teaching process. Theory into practice, 38 Number 1, 0040-5841. Retrieved March 7, 2010, from http://www.jstor.org/pss/1477204

22. Kelleher, T, O. M. \& Michelle. Applying the technology acceptance model to assess outcomes in a globally linked strategic communication project. Retrieved March 7, 2010, from http://vlex.com/source/journalismmass-communication-educator-4164/issue nbr/\%2360\%234

23. Kiraz, E., \& Ozdemir, D. (2006). The relationship between educational ideologies and technology acceptance in pre-service teachers. Educational Technology and Society, 9, 152-165.

24. Lau, S. H., \& Woods, P. C. (2008). An investigation of user perceptions and attitudes towards learning objects. British Journal of Educational Technology, 685-699.

25. Laursen, S., \& Rocque, B. Faculty development for institutional change: Lessons from an ADVANCE project. Retrived March 13, 2010, from http://www.changemag.org/Archives/Back\%20Issues/MarchApril\%202009/full-advance-project.html

26. Legris, P., Ingham, J., \& Collerette, P. (2003). Why do people use information technology? A critical review of the technology acceptance model. Information and Management, 40, 191-204.

27. Meister, D. B., \& Compeau, D. R. (2002). Infusion of innovation adoption: An individual perspective. 
Annual Conference of the Administrative Sciences Association of Canada (ASAC), May 25-28, Winnipeg, Manitoba: 23-33.

28. Moon, J. W., \& Kim, Y. G. (2001). Extending the TAM for a world-wide-web context. Information \& Management, 38, 217-230.

29. Ngai, E. W. T., Poon, J. K. L., \& Chan, Y. H. C. (2007). Empirical examination of the adoption of WebCT using TAM. Retrived March 12, 2010, from http://www.sciencedirect.com/science

30. Portal-e-Content: Voices from the Ground e-Content. Retrieved May 2, 2010, from econtentworldwide.org/folder.asp?folder=folder\&id=420\&...Philippines

31. Saade, R. G., Nebebe, F., \& Tan, W. (2007). Viability of the technology acceptance model in multimedia learning environments: A comparative study. Interdisciplinary Journal of Knowledge and Learning Objects, 3,175-184.

32. Sun, H., \& Xiao, X. (2008). User acceptance of virtual technologies. Fifth International Conference on eLearning for Knowledge-based Society, December 11-12, 2008, 1, 13.

33. Technology lifecycle. Retrieved January 12, 2010, from http://en.wikipedia.org/wiki/Technology lifecycle

34. Teo, T., Lee, C. B., \& Chai, C. S. (2008). Understanding pre-service teachers' Computer attitudes: Applying and extending the technology acceptance model. Journal of Computer Assisted Learning, 23, 128-143.

35. Thompson, R. L., Higgins, C. A., \& Howell, J. M. (1991). Personal computing: Toward a conceptual model of utilization. MIS Quarterly, 15, 124-143.

36. Tobing V., Hamzah, M., Sura S., \& Amin, Hanudin. A. Assessing the acceptability of adaptive E-learning system. special issue of the International Retrieved February 12, 2010, from http://www.elearningap.com/eLAP2008/Proceedings/13_fullpaper_Vianny\%20Tobing_Revised.pdf

37. University instructors' acceptance of electronic courseware: An application of the technology acceptance model. Retrieved February 15, 2010, from http://jcmc.indiana.edu/vol13/issue1/park.html

38. Wai-kit, W., Andersson, R., \& Streith, K. O. (2005). Examining user acceptance of computer technology: An empirical study of student teachers. Journal of Computer Assisted Learning, 21, 367-395.

39. Yi, M. Y., \& Hwang, Y. (2003). Predicting the use of web-based information systems: Self-efficacy, enjoyment, learning goal orientation, and the technology acceptance model. International Journal of Human-Computer Studies, 59, 431-449.

40. Yousafzai, S. Y., Pallister, \& J. G., Foxall, G. R. (2006). A meta-analysis of technology acceptance model. Retrieved April 5, 2010, from http://www.sciencedirect.com/science

41. Zarinah, M. K., \& Siti, S. S. (2009). A Web-based requirements elicitation tool using focus group discussion in supporting computer-supported collaborative learning requirements development. International Journal of the Computer, the Internet and Management, 41, 1-8.

42. Zumd, R. W. (1979). Individual differences and MIS success: A review of the empirical literature. Management Science, 25, 966-979. 